\title{
A NEGYEDIK IPARI FORRADALOM HATÁSA AZ ÉLELMISZERIPARRA: PERSPEKTÍVÁK ÉS GÁTLÓ TÉNYEZŐK
}

\author{
Vachter Dorina \\ logisztikai mérnök hallgató, Miskolci Egyetem, Logisztikai Intézet \\ 3515 Miskolc, Miskolc-Egyetemváros, e-mail: vachter.dorina@gmail.com \\ Bányai Tamás \\ egyetemi docens, Miskolci Egyetem, Logisztikai Intézet \\ 3515 Miskolc, Miskolc-Egyetemváros, e-mail: alttamas@uni-miskolc.hu
}

\begin{abstract}
Absztrakt
A negyedik ipari forradalom a gazdaság számos területén érezteti hatását. Találkozhatunk vele a gyártás/ellátás vizualizáció alkalmával, az ellátási lánc-, készlet és termeléstervezés optimalizálása közben, valamint az ERP (Enterprise Resource Planning-vállalatirányitási rendszer), MES (Manufacturing Execution System - gyártás végrehajtási rendszer) és SMC (Supply Chain Management- ellátási lánc menedzsment) használata közben is. Az élelmiszeriparban is új lehetöségeket teremt a fejlödésre, a hatékonyság növelésére, valamint a rendelkezésre álló kapacitások magasabb szinten történö kihasználására. Jelen cikk keretében a szerzök ismertetik az Ipar 4.0 helyzetét az élelmiszeriparban, illetve bemutatják az élelmiszeripar digitalizációjának felmérése által adódott eredményeket szakirodalmi források felhasználásával. Továbbá tárgyalják az élelmiszeripart érintő kihivásokat, illetve felvázolják az Élelmiszeripari Fejlesztési Stratégia föbb tartalmi elemeit. A cikk utolsó részében ismertetésre kerülnek az élelmiszeripar fejlödését gátló tényezök.
\end{abstract}

Kulcsszavak: Ipar 4.0, élelmiszeripar, digitalizáció, logisztika, ellátási lánc management

\begin{abstract}
The fourth industrial revolution has a great impact on many areas of the economy. It influences the processes during production / supply visualization, while optimizing supply chain, inventory and production planning, as well as ERP (Enterprise Resource Planning), MES (Manufacturing Execution System) and SMC (Supply Chain Management). It also creates new opportunities for development in the food industry, for increasing efficiency and for making better use of available capacities. Within the frame of this article, the authors describe the potentials of Industry 4.0 in the food industry and present the results of the survey on the digitization of the food industry using literature sources. They discuss the challenges affecting the food industry and outline the main content elements of the food industry development strategy. The last part of the article describes the factors that hinder the development of the food industry.
\end{abstract}

Keywords: Industry 4.0, food industry, digitisation, logistics, supply chain management

\section{Bevezetés}

A negyedik ipari forradalom szerepe egyre nagyobb mértékben megnövekszik a gazdaság szinte minden területén. Nem csupán az autóipar és a mechatronikai összeszerelő ipar, valamint az azokat ki- 
szolgáló logisztikai folyamatok fordulnak egyre nagyobb figyelemmel a dolgok internete kínálta lehetőségek felé, hanem az élelmiszeripar is egyre nagyobb lépéseket tesz abba az irányba, hogy felhasználva az Ipar 4.0 technológiák kínálta lehetőségeket, növelje folyamatai hatékonyságát, környezetbarát, energia- és költséghatékony rendszerek müködtetése révén biztosítsa termékei és folyamatai egyre jobb minőségét [1]. Olyan területek kerülnek egyre komolyabb kutatási projektek középpontjába, mint mesterséges intelligencia alkalmazások az élelmiszeriparban [2], Ipar 4.0 technológiák az élelmiszerfeldolgozás különböző speciális területein [3], innovációmanagement az élelmiszeriparban [4], blockchain technológiai kínálta lehetőségek a mezőgazdaságban és az élelmiszer nyersanyag termelésben [5,6], jövőbeli képességek felmérése az élelmiszeriparban [7], korszerü technológiák alkalmazása [8], bizonytalansági modellek az élelmiszerek iránti egyre dinamikusabban változó keresletek és a változó gyártási és piaci környezet leírására [9], jövőkutatás, milyen lesz a jövő élelmiszeripara a negyedik ipari forradalom technológiáinak alkalmazása révén [10,11].

Napjainkban egyre elterjedtebb az Ipar 4.0-ként is ismert 4. ipari forradalom. Ez egy korszak, amely az információs technológia és az automatizálás egyre szorosabb összefonódását eredményezi. A gyártási módszerek megváltozása mellett új gyártási módszerek születését is köszönhetjük neki, valamint az ipari digitalizációt, a folyamatok digitalizálását is. Ennek köszönhetően könnyebbé vált az optimalizálás és hatékonyabb, versenyképesebb termelés érhető el $[12,13]$.

Mindezen újítások nem lennének elérhetőek bizonyos tényezők nélkül. Az Ipar 4.0 alapja az M2M (machine to machine) technológia, amely lehetővé teszi a gépek egymás közötti kommunikációját, emberi közremüködés nélkül. Ennek eredményeképp a gépek képesek átvenni a komplexebb feladatok irányítását is, ezzel növelve az üzleti hatékonyságot. Az egyre nagyobb igény miatt mára egy dinamikusan fejlődő és bővülő iparággá nőtte ki magát [14].

A fentebb említett M2M technológia egy olyan információs csatorna meglétét feltételezi, mint például az IoT (Internet of Things), amely az egymással önállóan kommunikáló berendezések által használt hálózat. Ezen keresztül az érintett gépek óriási adatforgalmat bonyolítanak le és dolgoznak fel.

A folyamatos fejlődés következtében megszületett az Artificial Intelligence (AI), vagyis a mesterséges intelligencia (MI) is, amely a gépek logikus gondolkodásra és tanulásra való képességét jelenti. Ez magába foglalja azt is, hogy az említett gépek nemcsak a kifinomult, mindenre kiterjedő programozás révén tudják a feladatokat elvégezni, hanem a bonyolultabb, korábbról még nem ismert feladatokat önállóan, tudatosan oldják meg.

Ez a mesterséges intelligencia egyaránt támaszkodik a Big Data állományára, amely egy, az információs társadalom által elóállított, hatalmas mennyiségü adathalmaz, valamint a felhőalapú szolgáltatásokra is, amikor az adatokat, szoftvereket nem helyi adathordozókon, hanem egy szolgáltató eszközein, úgynevezett felhőkben tárolják. Ennek köszönhetően az információk internet segítségével bármikor, bárhonnan elérhetőek.

\section{Ipar 4.0 az élelmiszeriparban}

Az élelmiszer-feldolgozó iparban a nyomonkövetési rendszerek alkalmazása több mint 10 éve kötelező és a követelményeket a vállalkozások többsége teljesíteni is tudja. Kétségtelen, hogy a nyomonkövethetőség gyorsítása, az átláthatóság javítása ma is fontos feladat, de miután ezen a területen ma is müködő megoldásokat használ az ipar, a modernizáció és a versenyképesség-javítás szempontjából lényegesen nagyobb hatást lehet elérni, ha az Ipar 4.0 és a digitalizációra rendelkezésre álló erőforrásokat elsősorban azokra a területekre összpontosítják, ahol még nem, vagy csak korlátozottan használnak a gyakorlatban új megoldásokat. 
Az Ipar 4.0 lehetőségei és az ezek kihasználása érdekében megoldandó feladatai legnagyobb mértékben az üzemi gyártási folyamatok szabályozása, müködtetése, a higiénia, az élelmiszer-biztonság és a minőség javítása köré csoportosulnak, és ezt csak kiegészítik az információáramlás szervezésével, a logisztikával, a termelés adminisztrációs támogatásával és az ügyvitellel kapcsolatos feladatok. Szakértői becslések szerint a várható élelmiszeripari alkalmazások kb. $80 \%$-át lehetne a más iparágak számára már kidolgozott megoldások adaptálásával kifejleszteni és csak kb. 20\%-ánál lenne szükség teljesen új kutatás-fejlesztésre.

Az élelmiszeriparban az Ipar 4.0-hoz kapcsolódó megoldások terjedését nehezíti az ágazat egyedi és heterogén jellege, annak 33 szakágazata és szakágazatonkénti eltérő vállalati mérete, valamint az előállítandó termékkörök vagy éppen termékek is más-más fejlesztési irányokat és megoldásokat igényelnek [15].

Az élelmiszergazdaságban az iparhoz és a kereskedelemhez hasonlóan új szervezeti formák jelentek meg, amelyek integrálják a termelést, feldolgozást, kereskedelmet, valamint kutatás-fejlesztést. Ezek mellé társul a globalizáció hatása is, amely reménnyel jogosít arra, hogy a jövőben környezetmegőrző és fenntartható agrártechnológiák biztosíthatják a jövő emberiségének élelmezését.

A fent említett okok miatt az élelmiszergazdaságban rohamosan terjednek azok a technológiák, amelyek megalapozzák a tudományos kutatásokon alapuló termelési rendszereket, a tömegtermelést, valamint a mezőgazdaság és az ipar integrációját. Egyre inkább teret hódítanak az integrált termelési technológiák és a robotok, továbbá a tudományágak termelésbe integrálása is folyamatosan gyarapszik.

A digitalizáció, az Ipar 4.0 és a fejlett gyártástechnológiák számos új képessé tévő funkciót és alkalmazási lehetőséget kínálnak, amelyek megoldást nyújtanak az élelmiszeripari vállalatok igényeire és problémáira, javítva versenyképességüket [16,17].

Főbb előnyeik az élelmiszeripar számára:

- Költségcsökkentés: az erőforrások hatékony felhasználása - energia, víz, alapanyagok, adalékanyagok, csomagolóanyag, munkaerő - és az anyagáram tekintetében.

- A kapacitáskihasználás javítása:

○ a termékváltások közötti átállási idő csökkentésével,

○ a karbantartások elörejelzésével,

○ az állásidők csökkentésével,

○ a folyamatok optimalizálása, tervezése és szimulálása által.

- Technológiai háttér új termékek és szolgáltatások kifejlesztéséhez.

- A munkaerő hatékonyságának és termelékenységének fokozása.

- A fogyasztói igényeknek megfelelő kisebb terméktételek gyártása a tömeggyártáséhoz hasonló költségek mellett.

- Az élelmiszer-biztonság és -minőség hatékonyabb szabályozása.

2018. áprilisában a kormány által elfogadásra került a „Magyarország Élelmiszergazdasági Koncepciója 2017-2050" címủ tervezet, amely az elkövetkezendő 33 évre kíván célkitüzéseket és beavatkozási irányokat nyújtani az élelmiszergazdaság 3 nagy szektorának- a mezőgazdaságnak, az élelmiszeriparnak és az élelmiszerkereskedelemnek. Ennek célja a hazai élelmiszergazdaság folyamatos fejlesztése, az újabbnál újabb kihívások legyőzése és a termelékenység növelése [18]. A terv összeállítása során vizsgálták a hazai élelmiszeripari vállalkozások digitalizációját; ennek részeként az informatikai infrastruktúrát és internethasználatot, a müködésben lévő vállalatirányítási rendszereket, a döntéstámogató és üzleti elemző eszközök használatát, valamint az ipar 4.0 technológia általános jelenlétét a vállalkozásokban $[19,20]$. 
2019 tavaszán egy anonim kérdőíves felmérés valósult meg a Debreceni Egyetem Ihrig Károly Doktori Iskola (DE IKDI), a NAIK Agrárgazdasági Kutatóintézet (NAIK AKI) és a Nemzeti Agrárgazdasági Kamara (NAK) együttmüködésével, amelyet több mint 200 vállalkozás töltött ki [21].

A felmérés célja a hazai élelmiszeripari vállalkozások digitalizációjának megismerése volt az informatikai infrastruktúra és internethasználat, a vállalatirányítási rendszerek, a döntéstámogató és üzleti elemző eszközök használata és szerepe, valamint az Ipar 4.0 technológiai váltással kapcsolatban.

A felmérés során kiderült, hogy a válaszadó vállalkozások $61 \%$-a használ olyan kéziszámítógépeket, mint például a tablet vagy az okostelefon. 66\%-uk alkalmaz munkája során hordozható személyi számítógépet, például laptopot, notebookot, míg 16\%-uk egyáltalán nem használ asztali számítógépet. A megkérdezettek 42\%-a használ különböző szervert vagy szervereket, 30\%-uk pedig igénybe vesz olyan felhő alapú szolgáltatásokat, mint a tárhely. A kitöltők mindössze 9\%-a szavazott arra, hogy tevékenysége során ipari PC-t használ.

Az említett kérdőívek alapján kijelenthető, hogy a termelési potenciál kihasználatlan, az élelmiszeripari vállalatokra gyenge versenyképesség és gyenge jövedelemtermelő képesség jellemző. A kihasználatlan kapacitások gyenge hatékonyságot eredményeznek, amely a kül- és belpiaci tevékenységek romlásához vezet.

A felmérésből többek között kiderült az is, hogy a vállalatok digitalizáció és integráció szintje saját bevallásuk szerint is igen alacsony, az élelmiszeripari szereplők többsége pedig nem tud az új technológiákról, lehetőségekről, ezen felül nincsenek tisztában az ezek alkalmazásával járó előnyökkel. Tovább nehezíti a helyzetet, hogy a fejlesztők nem ismerik az ágazatot érintő nehézségeket, valamint a problémákat.

A beruházásokkal kapcsolatban gyakori tapasztalat volt, hogy a cégek használt gépeket vásárolnak, felújítják a meglévő berendezéseket és csak korlátozottan tudnak gépet cserélni, így mindig akad a technológiában 1-1 elavult, nem hatékony elem. Sok válaszadó elégedett a 10-20 éves berendezésekkel, azaz már igénye sincs a korszerüsítésre, mert úgy véli, hogy a modernebb sem feltétlenül hatékonyabb.

Az anyagiak kérdése újabb problémákat vet fel, ugyanis az élelmiszeriparra jellemző, hogy az ágazat pénzügyi eredménye negatív, köszönhetően az ágazat erős eladósodottságának, és az ezzel járó jelentős kamat- és törlesztő kiadásoknak, valamint az árfolyam ingadozások káros hatásainak. Az ágazat müködésében a pénzügyi veszteség meghatározó az eredményesség szempontjából. A jelentős pénzügyi veszteség mellett a folyamatosan növekvő hitelállomány is nagy nyomást jelent az élelmiszergazdaság valamennyi szereplője számára. A tőkehiány alapvetően a magyar tulajdonban lévő élelmiszeripari vállalkozásokat sújtja, éppen ezért az élelmiszeripar müködését jelentősen befolyásolja a külföldi tőke jelenléte, melynek aránya kiemelkedő - a szakágazatok közel harmadában meghaladja a $80 \%$-ot.

A képzetlen munkaerő további kihívások elé állítja az élelmiszeripart, ugyanis a jelenlegi agrárinformatikai és digitális megoldások alkalmazásához nincs megfelelő képességü és képzettségü munkaerő, ezáltal az innovációs eredmények hasznosítása is romlik.

Az egyre növekvő élelmiszerbiztonsági követelmények hatására nőnek az alapanyagokkal, félkészés késztermékekkel szemben támasztott követelmények, ezért szükségessé válnak a piaci igényeknek megfelelő, minőségorientált termesztési technológiák alkalmazásai.

A többi iparághoz hasonlóan az élelmiszergazdaság valamennyi területén szintén megjelent a növekvő energia- és erőforrásigény, amely a megújuló energiák és erőforrások használatára ösztönzi a mezőgazdaság és élelmiszeripar szereplőit a fenntarthatóság és környezetvédelem javítása érdekében.

A saját feldolgozóipari és értékesítési (disztribúciós) háttér nélkül a magyar termelők sokkal kitettebbek a nemzetközi piacok és kereskedelem hullámzásainak, mint versenytársaik. A szervezett 
együttmüködés, a szövetkezeti és gazdatársulási forma a termelők gazdasági hátterének stabilizálásán túl lehetőséget teremt korábban számukra el nem ért értékesítési csatornák használatára, közvetlen piaci visszacsatolást jelent a termelőnek, minőségi garanciát és nyomon követést nyújt a fogyasztónak.

A hazai piac megtartása is kiemelt fontosságú, azonban emellett a nemzetközi piaci lehetőségek kiaknázása komoly lehetőséget jelent az élelmiszeripar számára mind bevétel, mind profit tekintetében, azonban az exportképesség javításához innovatívabb áruszerkezetre, a célpiacok igényeinek jobb megismerésére és erősebb marketingtevékenységre lenne szükség.

A termelés zavartalan müködése érdekében az akadálytalan információáramlás alapvető fontosságú, az élelmiszergazdaság valamennyi szereplőjének megfelelő és gyors információval kell rendelkeznie a piaci folyamatokról és fejleményekröl, a támogatások és szabályozások változásairól. A szabad információáramlás, az információk és a tudás megfelelő menedzselése érdekében az élelmiszergazdaság résztvevői között elő kell segíteni olyan felhasználóbarát, rendszerbe szervezett csatornák kialakulását, amelyek képesek az információk és a tudás iránti kereslet és kínálat összehangolására, hiszen a szereplők nem maradhatnak egymástól elszigeteltek.

\section{3. Élelmiszeripari fejlesztési stratégia}

Magyarországon az Ipar 4.0 és a digitalizáció alkalmazása az élelmiszer-feldolgozó iparban jelenleg korlátozott mértékü, és elsősorban a logisztikai rendszerekre, a készletnyilvántartásra és az ügyvitelre irányul $[22,23]$.

Ezért is volt szükség arra, hogy az élelmiszer-feldolgozó vállalkozások kidolgozzanak egy olyan, a digitalizáció és az Ipar 4.0 élelmiszeripari alkalmazására vonatkozó ágazati stratégiát, amely az élelmiszer-feldolgozás anyagáramlási folyamatainak és a munkaerő ehhez kapcsolódó felhasználásának optimalizálását helyezi a középpontba. Ennek eredményeképpen született meg 2015-ban az Élelmiszeripari Fejlesztési Stratégia (ÉFS), amely a kormány részéről egyfajta iránymutatásként funkcionál az élelmiszeripar fejlesztése érdekében [24,25].

Ez a stratégia az élelmiszeripar szereplői számára jelöli ki az ezen a területen megvalósítandó fejlesztés fó irányait. A stratégia alapvető célja valamennyi vállalkozás típusnál a versenyképesség javítása, továbbá az élelmiszeriparban foglalkoztatottak számának növelése, valamint a hazai mezőgazdasági alapanyag-termeléshez közvetlenül kapcsolódó vidéki munkahelyek megörzése és gyarapítása.

A stratégia a kiemelt célok közé sorolja a vállalkozások stabil finanszírozását, a kiegyensúlyozott gazdálkodás javítását, innovatív, hatékony vállalkozások elősegítését, a termékpályák szerinti fejlesztést, a megfelelő képzettségü, gyakorlott, motivált munkatársak képzését, a termékpálya szereplői közötti horizontális és vertikális kapcsolatok erősítését, továbbá a közösségi marketing és egyéb eszközök felhasználásával a magyar élelmiszerek ismertségének, jó hírnevének erősítését. További fontos cél, hogy Magyarország holland minta alapján disztribúciós központtá váljon.

A hazai termelés és piac hatékonyabb szervezésével, a feldolgozottság növelésével a világban lévő fizetőképes keresletre való célirányos reagálással a magyar élelmiszer-gazdaságban a mostaninál szakmai becslések szerint 60\%-kal nagyobb termelési potenciál van.

\section{Az élelmiszeripar fejlődését gátló tényezők}

Az Ipar 4.0 és a digitalizáció területén való fejlödéshez elengedhetetlen a technológiai fejlődés, azonban ez számos kihívást tartogat a vállalatok számára. Ezen kihívások mellett a már említett vállalkozásoknak a mindennapi müködés során tapasztalt általános problémákkal is meg kell küzdeniük [26]. 
2018-ban készült egy felmérés, amely többek között a „Milyen általános problémákkal találkozik a mindennapi müködés során?" kérdésre kereste a választ. 51 vállalkozás válaszolt a feltett kérdésre, közülük legtöbben - pontosabban 30-an - a munkaerőhiányt jelölték meg. Sokan választották még az adórendszert, a magas költségeket, a szakképzett munkaerő hiányát és a jogszabályi hátteret a mindennapi problémák forrásaként. Az adminisztratív feladatok mellett a környezetvédelmi és politikai kérdések, a pénzügyi és beszállítói problémák és a konkurencia erősödése is gondot okoz. A válaszadók közül néhányan az információhiányt, a gyorsuló technológiai fejlődést, az oktatás alacsony színvonalát és a gyorsan változó vevői igényeket teszik felelőssé a nehézségek miatt. Ugyan elenyésző számban, de néhány kitöltő választotta a bonyolult szerkezeti felépítést, a vevők, piacok szükülését, valamint a túlzott manualitást a munkavégzés során, továbbá valamennyi válaszadó az egyéb opció mellett is letette voksát.

\section{5. Összefoglalás}

Jelen publikáció keretében a szerzők összefoglalták azokat a főbb szempontokat, melyek révén a negyedik ipari forradalom keretei között az élelmiszeripar fejlődése várható. A negyedik ipari forradalom lehetőséget nyit arra, hogy az élelmiszeripari cégek a dolgok internete révén hagyományos rendszereiket kiber-fizikai rendszerekké alakítsák át hatékonyságuk fokozása érdekében. Mivel ez a transzformáció mind horizontális, mind vertikális integrációs elemeket is tartalmaz, ezért elkerülhetetlen, hogy az élelmiszeripari ellátási láncok olyan komplex rendszerekké alakuljanak át, melyek az angol nyelv a magyarra nehezen fordítható hyperconnected vagy interconnected szavakkal ír le.

A szerzők jövőbeli tervei között szerepel az élelmiszeripari ellátási láncok néhány, a horizontális integráció részeként jelentős szerepet vállaló tagjának felülvizsgálata azon szempontból, hogy milyen lehetőségek vannak a hatékonyság Ipar 4.0 technológiák révén történő növelésére.

\section{Irodalom}

[1] Borowski, P.F. Innovative Processes in Managing an Enterprise from the Energy and Food. Sector in the Era of Industry 4.0. Processes 2021, 9(2):381. https://doi.org/10.3390/pr9020381

[2] Konur, S., Lan, Y., Thakker, D., Morkyani, G., Polovina, N., Sharp, J. Towards design and implementation of Industry 4.0 for food manufacturing. Neural Computing and Applications 2021. https://doi.org/10.1007/s00521-021-05726-Z

[3] Jambrak, A.R., Nutrizio, M., Djekic, I., Pleslic, S., Chemat, F. Internet of Nonthermal Food Processing Technologies (IoNTP): Food Industry 4.0 and Sustainability. Applied SciencesBasel 2021, 11(2):686. https://doi.org/10.3390/app11020686

[4] Oltra-Mestre, M.J., Hargaden, V., Coughlan, P., del Rio, B.S.G. Innovation in the Agri-Food sector: Exploiting opportunities for Industry 4.0. Creativity and Innovation Management 2021, 30(1): 198-210. https://doi.org/10.1111/caim.12418

[5] Kayikci, Y., Subramanian, N., Dora, M., Bhatia, M.S. Food supply chain in the era of Industry 4.0: blockchain technology implementation opportunities and impediments from the perspective of people, process, performance, and technology. Production Planning \& Control 2020. https://doi.org/10.1080/09537287.2020.1810757

[6] Khan, P.W., Byun, Y.C., Park, N. IoT-Blockchain Enabled Optimized Provenance System for Food Industry 4.0 Using Advanced Deep Learning. Sensors 2020, 20(10): 2990. https://doi.org/10.3390/s20102990 
[7] Akyazi, T., Goti, A., Oyarbide, A., Alberdi, E., Bayon, F. A Guide for the Food Industry to Meet the Future Skills Requirements Emerging with Industry 4.0. Foods 2020, 9(4): 492. https://doi.org/10.3390/foods9040492

[8] Show, P.L., Chew, K.W., Leong, H.Y. Advanced Food Process Technologies: Bridging Conventional Practices to Industry 4.0. Current Nutrition \& Food Science 2020, 16(9):1286. https://doi.org/10.2174/157340131609201022105040

[9] Simon, J., Trojanova, M., Zbihlej, J., Sarosi, J. Mass customization model in food industry using industry 4.0 standard with fuzzy-based multi-criteria decision making methodology. Advances in Mechanical Engineering 2018, 10(3): 1687814018766776. https://doi.org/10.1177/1687814018766776

[10] Bucking, M., Hengse, A. Food Industry 4.0 The Food Industry must innovate purely. Deutsche Lebensmittel-Rundschau 2016, 112(6): 256-260.

[11] Creydt, M., Fischer, M. Food Industry 4.0 Chances and Strategies for the Food Industry. Deutsche Lebensmittel-Rundschau 2016, 112(1): 24-30.

[12] Mit is jelent pontosan az ipar 4.0? 5 példagyár már példát mutat. Elérhetőség: https://mfor.hu/cikkek/continental-technologiai-sarok/mit-is-jelent-pontosan-az-ipar-4-0-5mintagyar-mar-peldat-mutat.html. Letöltve: 2021.02.14.

[13] Barkovits, B. Tisztázzuk az ipar 4.0 alapfogalmait! Elérhetőség: https://autopro.hu/trend/tisztazzuk-az-ipar-4-0-alapfogalmait/170408 Letöltve: 2021.01.06.

[14] $\mathrm{Mi}$ az M2M? Elérhetőség: https://www.telekom.hu/uzleti/szolgaltatasok/egyebszolgaltatasok/m2m Letöltve: 2020.12 .02 .

[15] Egri, I. Az Ipar 4.0 hatása az élelmiszergazdaságra. Jelenkori társadalmi és gazdasági folyamatok 2019, 14(3): 91-101.

[16] Az Ipar 4.0 és az élelmiszeripar Elérhetőség: https://nkfih.gov.hu/hivatalrol/nyomtatottsajto/ipar-4-0-elelmiszeripar Letöltve: 2021.02.11.

[17] Ipar 4.0 az élelmiszergyártásban Elérhetőség: http://elelmiszeripar.hu/2019/04/17/ipar4-azelelmiszerigyartasban/ Letöltve: 2021.02.14.

[18] Magyarország élelmiszergazdasági koncepciója 2017-2050 Elérhetőség: https://20152019.kormany.hu/download/0/07/11000/\%C3\%89lelmiszergazdas\%C3\%A1 gi\%20Program\%20 2017-2050.pdf Letöltve: 2021.01.11.

[19] Debrenti, A.S. A digitalizáció helyzete a magyar élelmiszer-feldolgozó ágazatban. International Journal of Engineering and Management Sciences 2020, 5(1): 196-209. https://doi.org/10.21791/IJEMS.2020.1.17

[20] Debrentei, A. S., Gaál, M. Élelmiszeripari vállalkozások digitalizációja. 2019.

[21] Trapp, H. Ipar 4.0 az élelmiszeriparban. Felmérték az élelmiszeripar digitalizációját Felmérték az élelmiszeripar digitalizációját Elérhetőség: http://storeinsider.hu/gazdasag/cikk/elelmiszer_gazdasagunkban_60_szazalekkal_nagyobb_term elesi_potencial_van Letöltve: 2020.11.23.

[22] A hazai élelmiszeripar jelene és jövője Elérhetőség: https://www.nak.hu/kamara/kamaraihirek/orszagos-hirek/92371-ordogi-korben-az-elelmiszeripari-vallalkozasok Letöltve: 2021.03.02.

[23] Nagy, I. Az élelmiszeripar stratégiai ágazat. Elérhetőség: https://drnagyistvan.hu/azelelmiszeripar-strategiai-agazat/ Letöltve: 2021.03.02.

[24] Kürthy, Gy., Dudás, Gy., Felkai, B. O. A magyaroroszági élelmiszeripar helyzete és jövőképe. Agrárgazdasági Kutató Intézet 2016. http://dx.doi.org/10.7896/at1603 
[25] Magyaroroszág közép- és hosszú távú élelmiszeripari fejlesztési stratégiája. Elérhetőség: https://elelmiszerlanc.kormany.hu/download/4/db/f0000/\%C3\%89lelmiszeripari\%20Fejleszt\%C 3\%A9si\%20Strat\%C3\%A9gia.pdf Letöltve: 2020.12.12.

[26] Kiderült, mi lehet a megoldás a magyar élelmiszeripar legnagyobb problémáira Elérhetőség: https://www.agrarszektor.hu/elemiszer/kiderult-mi-lehet-a-megoldas-a-magyar-elelmiszeriparlegnagyobb-problemaira.20121.html Letöltve: 2021.01.10. 